\title{
EXTRACTION AND EVALUATION OF TOTAL DIETARY FIBERS FROM SOME VEGETABLES
}

\author{
Abdullah M. Thannoun \\ Karam W. Younis
}

Food Sci. Dept., College of Agric. and Forestry, Mosul University, Iraq.

E-mail: dr_thannoun@yahoo.Com

\begin{abstract}
Functional properties of dietary fibers extracted from some vegetables namely; celery, parsley, red and dark radish, green beans and peas and tomato peels using enzymatic method were investigated. Dietary fibers were investigated for yield extraction and water holding capacity (WHC), oil holding capacity $(\mathrm{OHC})$ and bulk density (BD). Results show that the extraction process gave acceptable yield of fibers from all vegetables and the highest yields were for green beans and peas and tomato peels $(24.04,25.89$ and $27.61 \%$, respectively). Bulk densities values were ranged between $0.300 \mathrm{~g} / \mathrm{ml}$ for dietary fibers from tomato peels to $0.667 \mathrm{~g} / \mathrm{ml}$ for dark radish compared with $0.500 \mathrm{~g} / \mathrm{ml}$ for commercial cellulose. WHC of extracted fibers were ranged between the highest values of 9.277 and $8.503 \mathrm{~g} / \mathrm{g}$ at respective $1350 \mathrm{Xg}$ and $2670 \mathrm{Xg}$ centrifugation speeds for tomato peels fibers and the lowest values of $5.207 \mathrm{~g} / \mathrm{g}$ and $4.771 \mathrm{~g} / \mathrm{g}$ at respective $1350 \mathrm{Xg}$ and $2670 \mathrm{Xg}$ centrifugation speeds for fibers of green peas compared with values of 4.107 and $3.367 \mathrm{~g} / \mathrm{g}$ at respective above centrifugation speeds for commercial cellulose. The lowest $\mathrm{OHC}$ at $1350 \mathrm{Xg}$ and $2670 \mathrm{Xg}$ centrifugation speeds were 5.910 and $3.809 \mathrm{~g} / \mathrm{g}$, respectively for green peas and the highest values were 6.527 and $5.593 \mathrm{~g} / \mathrm{g}$, respectively for parsley compared with 5.910 and $4.290 \mathrm{~g} / \mathrm{g}$, respectively for commercial cellulose. It was concluded that these vegetable were good sources of dietary fibers with good functional properties of endurable healthy purpose.

Keywords: Cellulose; Dietary fibers; Oil Holding Capacity; Vegetables; Water Holding Capacity.
\end{abstract}

Received: 9/4/2012 Accepted: 21/5/2012

\section{INTRODUCTION}

Since years ago, general population knew and used the concept the bulk or roughage which have related to nutrition, to refer to part of the plant food components, now defined as fibers. This component of the food for a long time thought to be an inert and insignificant nutrient. In the early 1950s, Hipsley (1953) was the first to use the term dietary fibers to describe a nutritional property of diets. In the 1970s, however, researchers suggested that fiber might have additional links to human health benefits. Dietary fibers have been defined in a variety of ways. Trowell (1976) defined them as plant substances not digested by human digestive enzymes, including plant cell wall substances (cellulose, hemicellulose, pectin and lignin) as well as the intercellular polysaccharides such as gums and mucilages. More recently, they were described by Anonymous (2001) as the edible parts of plants or analogous carbohydrates that are resistant to digestion and absorption in the human small intestine with complete or partial fermentation in the large intestine. It is important to know that the natural sources of fibers are only plant 
foods. All plants contain some fiber and different kinds of plants vary in their amount and kind of fiber, but plants with high fiber contents are generally the most valuable sources for the foods (Anonymous, 1996). Dietary fibers are basically divided into soluble and insoluble fibers (Brown et al., 1999) in which individually or collectively have several physiological and metabolic effects which may be important for human health. Several of colonic disorders and metabolic diseases, notably cardiovascular disease, colonic cancer, diabetes, diverticulosis and obesity, are inversely related to dietary fiber consumption (Trowell, 1976; Sreenath et al., 1996; Weickert, et al., 2005 and Anderson et al., 2009).

Information about sources and composition of dietary fibers of most of our foods is not available in which is very necessary in determining their physiological effects. Further, to get starte on adopting a diet rich in fiber, it helps to know which foods of our diet offer the greatest sources of fibers and how to identify them in proper. The aim of this study was to prepare, extract and evaluate dietary fibers from some vegetables.

\section{MATERIALS AND METHODS}

Samples Preparation: Fresh vegetables using in our local salad namely, celery, parsley, red and dark radish, green beans and peas and tomato peels were obtained from a local market in Mosul city, Iraq. All vegetables were washed by tap water and damaged parts and foreign materials were removed and analyzed for approximate analysis as a fresh. Clean fresh vegetables were chopped in stainless steel trays and dried for $24 \mathrm{~h}$ at $50^{\circ} \mathrm{C}$ in vacuum oven (Proodit-59-10026-Italy). The tomato peels were obtained after juice extracted by electric home extractor or blender. The seeds were discarded and tomato peels were taken and dried in the same method. The dried material was ground using a mortar and pestle to a particle size smaller than $0.7 \mathrm{~mm}$. The powders were packed in well-sealed polyethylene sacs, labeled and stored in refrigerator until next steps of research.

Chemical Analysis was performed as followed: Moisture was determined according to method mentioned in Anonymous (2000) using electric vacuum oven made by Memmert Company, Germany at $105^{\circ} \mathrm{C}$ and $100 \mathrm{mmHg}$ pressure. Ash was determined according to method mentioned in Anonymous (2000) using Muffle Furnace made by Cole-Parmer Box Furnace, USA at $550^{\circ} \mathrm{C}$ overnight or to complete ashing by obtaining white ash. Fibers were determined using method mentioned in Anonymous (2000). Fat was determined by Soxhlet apparatus using method mentioned in Anonymous (2000). Protein was determined by Macrokjeldahl method using technique mentioned in Anonymous (2000). However, carbohydrates were calculated by difference.

Enzymatic Method of Dietary Fibers Extraction: Dietary fibers were extracted followed a preparative technique described by Bunzil et al. (2005) and Anonymous (2000) with some modifications. In the first step, fat was extracted and removed by Soxhlet apparatus to get fat free powder. Then, starch was degraded in a phosphate buffer at $\mathrm{pH} 6.0$ using heat stable bacterial $\alpha$-amylase (Himedia Company, India) and incubated at $90{ }^{\circ} \mathrm{C}$ for $30 \mathrm{~min}$. The suspension was centrifuged (4000 rpm) and washed thoroughly with distilled water. Then procedures were followed by treated the residue with protease for degradation of protein after adjusting the $\mathrm{pH}$ at 7.5 and incubating the suspension at $60^{\circ} \mathrm{C}$ for $30 \mathrm{~min}$. These procedures were followed by amyloglucosidase degradation (Himedia Company, India) at $\mathrm{pH} 4.5$ and $60{ }^{\circ} \mathrm{C}$ for 
$30 \mathrm{~min}$ ). Following centrifugation (4000 rpm for $10 \mathrm{~min}$ ), the residue was washed three times with warm water $\left(70^{\circ} \mathrm{C}\right)$ and once with $95 \%(\mathrm{v} / \mathrm{v})$ ethanol and acetone and finally dried at $40{ }^{\circ} \mathrm{C}$ overnight in a vacuum oven. The dried residues were further extracted with ethanol $(8 \mathrm{~h})$, dichloromethane $(8 \mathrm{~h})$, and $n$-hexane $(8 \mathrm{~h})$ using a Soxhlet apparatus. After each treatment centrifugation was performed before drying at $50{ }^{\circ} \mathrm{C}$ overnight in a vacuum oven. The residues were washed again by alcohol, Dichloromethane and hexane using also a Soxhlet apparatus and then with distilled water before dried at $50{ }^{\circ} \mathrm{C}$ overnight in a vacuum oven. To get more patches of dietary fibers, the extracted dried plant materials were doubled. Dietary fiber was collected through a 500-mesh sieve, weighed and packed in polyethylene sacks and stored in cooled and dried place for next step. Water and Oil Holding Capacity (WHC and OHC): Water and Oil Holding Capacity was performed using technique published by Yashimoto et al. (2005) with some modification. A quantity of $0.15 \mathrm{~g}$ of extracted dietary fibers was precisely weighed in dried centrifuge graduated test tubes and shacked vigorously to packed fibers in order to measures their volumes. To these tubes water or sunflower oil was added until the tube contents to weigh $15 \mathrm{~g}$. The mixture in tubes was suspended and homogenized for $10 \mathrm{~min}$ using kahn-shaker homogenizer (Italian made). The suspension was centrifuged at 1240 and $2470 \mathrm{X}$ g for 10 and 20 min,respectively and the precipitate was weighed and volume estimated. Water and oil holding capacities were measured by the weight of the water or oil that $1 \mathrm{~g}$ of dietary fibers to contain or to have capacity for. Capacity values were compared with that of commercial cellulose (Wattman International Ltd, England).

Bulk Density (BD): The same first step in water holding capacity determination was used to determine the bulk capacity in which certain quantity of DF was weigh $(0.15 \mathrm{~g})$

in weigh clean dry graduated test tube. The volume of the compact content was measured after vigorous shaking of the tube contents using the same above shaker and the bulk or packed density was calculated as weight/volume. It was calculated as weight per lowest volume of sample. Density values were compared with that of commercial cellulose.

Statistical Analysis: Data were analyzed by one way analysis of Variance and Standard deviations were calculated by using Duncan's Multiple Range Test (Steel and Torrie, 1980).

\section{RESULTS AND DISCUSSION}

Different vegetables and some of their byproducts which were used as sources of dietary fibers were analyzed for their proximate contents (protein, lipids or fat, ash, fibers and carbohydrates) as shown in Table (1). Results show that these vegetables were considered as good sources of dietary fibers and other nutrients on dry basis. Protein contents of the sources ranged between the lowest values of $10.0 \%$ in celery to the highest values of 29.1 and $29.8 \%$ in green beans and peas, respectively. However, these materials were naturally poor sources of fat, in which the ether extracts were ranged between $0.9 \%$ as lowest value to the highest value of $6.9 \%$ in tomato peels. The data show that these dried materials were high in ash which is considered as a result of minerals content found in these materials. Specifically, dried celery and parsley contained 18.6 and $18.1 \%$ ash, respectively, whereas lower values (3.6 and 4.09\%) were found in green peas and beans, 
respectively. Table (1) also shows the considerable fibers content of these vegetables. From the data in the same Table, fibers ranged between the lowest values of $8.2 \%$ in green peas and the highest value of $19.5 \%$

Table (1): Chemical composition of vegetables, on dry basis (g/100g).

\begin{tabular}{|l|c|c|c|c|c|}
\hline Vegetables & Protein & Fat & Ash & Fibers & Carbohydrates* \\
\hline Celery & 10.0 & 2.23 & 18.6 & 8.8 & 60.37 \\
\hline Parsley & 12.25 & 4.33 & 18.2 & 9.0 & 56.22 \\
\hline Red Radish & 14.9 & 0.9 & 13.2 & 10.4 & 60.6 \\
\hline Dark Radish & 14.9 & 1.1 & 11.9 & 12.1 & 60.0 \\
\hline Green beans & 29.1 & 2.6 & 4.09 & 9.1 & 55.11 \\
\hline Green peas & 29.8 & 3.02 & 3.6 & 8.2 & 55.38 \\
\hline $\begin{array}{l}\text { Tomato } \\
\text { peels }\end{array}$ & 11.2 & 6.9 & 9.7 & 19.5 & 52.7 \\
\hline
\end{tabular}

Numbers represents average of three samples.

*By difference.

in tomato peels. Little higher comparable analysis of tomato peels (10. 08 and 29.9\% protein and fibers, respectively) was observed by Knoblich et al. (2005). Between these values, radishes were also considered as good sources of fibers in which contained relatively high values $(10.4$ and $121 \%$ in red and dark radish, respectively). Values of this study for all nutrients in Table (1) were comparable with the values mentioned by Dalaly and Al-Hakim (1987) and in agreement with those recently tabulated in (Anonymous, 2011).

Yield of Extraction:Table (2) shows the extraction profile of dietary fibers from different vegetables using enzymatic method. The Table shows that the extraction method started with using dried vegetables powder particles size of $<700 \mathrm{~mm}$ and yielding of dietary fibers particles size of $<500 \mathrm{~mm}$. The fibers content of the different sources ranged between $10.97 \%$ for celery and $27.61 \%$ for tomato peels. The extraction process showed a higher extraction yield which was exceeded acceptable yield of fibers for green beans and peas and tomato peels $(24.04,25.89$ and $27.61 \%$, respectively).

Table (2): Enzymatic extraction of dietary fibers from some vegetables.

\begin{tabular}{|l|c|c|c|c|}
\hline Vegetables & $\begin{array}{c}\text { Initial weight } \\
(\mathrm{g})\end{array}$ & $\begin{array}{c}\text { Initial Particles } \\
\text { size }(<\mathrm{mm})\end{array}$ & $\begin{array}{c}\text { Total Dietary } \\
\text { fibers yield }(\mathrm{g})\end{array}$ & $\begin{array}{c}\text { Final Particles } \\
\text { size }(<\mathrm{mm})\end{array}$ \\
\hline Celery & 100 & 0.7 & 10.97 & 0.5 \\
\hline Parsley & 100 & 0.7 & 15.18 & 0.5 \\
\hline Red Radish & 100 & 0.7 & 19.72 & 0.5 \\
\hline Dark Radish & 100 & 0.7 & 20.86 & 0.5 \\
\hline Green bean & 100 & 0.7 & 25.89 & 0.5 \\
\hline Green peas & 100 & 0.7 & 24.04 & 0.5 \\
\hline Tomato peels & 100 & 0.7 & 27.61 & 0.5 \\
\hline
\end{tabular}

Final volumes occupied by the various dietary fibers of different sources and bulk or packed densities are shown in Table 3. From the Table, results show that the same weight of different dietary fibers occupied deferent volume of the space. Dietary fibers of tomato peels occupied highest volume of $0.5 \mathrm{ml}$ compared with the lowest volume of $0,225 \mathrm{ml}$ for dietary fibers extracted from dark radish. 
Consequently, Bulk or packed densities values were ranged between $0.300 \mathrm{~g} / \mathrm{ml}$ for dietary fibers from tomato peels to $0.667 \mathrm{~g} / \mathrm{ml}$ for dark radish compared with 0.500 $\mathrm{g} / \mathrm{ml}$ for commercial cellulose. Both kinds of dietary fibers of red and dark radishes had higher densities (600 and $0.667 \mathrm{~g} / \mathrm{ml}$, respectively) compared with $0.500 \mathrm{~g} / \mathrm{ml}$ for commercial cellulose. This was due to the size of dietary fibers particles in which weighed more weight for smaller once in certain volume. Bulk and packed density of the fibers depends on the shape

and size of the particles (Prakongpan et al., 2001). They stated that large-size particles showed higher bulk density than the small-size ones, whereas in case of packed density the smaller particles gave a higher density values than the larger once. In animals like hamsters, particle size and treatment were also important in affecting physiological functions of fibers and the consumption of micronized fiber might exert favorable effects on improving the intestinal health (Wu et al., 2006).

Table (3) also shows the Water-holding capacity of the extracted dietary fibers recorded after using two centrifugation speeds $1240 \mathrm{Xg}$ for $10 \mathrm{~min}$ and $2470 \mathrm{Xg}$ for $20 \mathrm{~min}$. Water holding capacity of these fibers were ranged between the highest values of 9.277 and $8.503 \mathrm{~g} / \mathrm{g}$ at respective $1240 \mathrm{Xg}$ and $2470 \mathrm{Xg}$ centrifugation speeds for tomato peels fibers and the lowest values of $5.207 \mathrm{~g} / \mathrm{g}$ and $4.771 \mathrm{~g} / \mathrm{g}$ at respective $1240 \mathrm{Xg}$ and $2470 \mathrm{Xg}$ centrifugation speeds for green peas fibers compared with values of 4.107 and $3.367 \mathrm{~g} / \mathrm{g}$ at respective above centrifugation speeds for commercial cellulose. Results of the same Table also show that the volume of hydrated fibers was relatively increased differently among the fibers. The hydrated dark radish fibers was increased to highest value of $4.444 \mathrm{ml} / \mathrm{ml}(4.444$ times) and $3.555 \mathrm{ml} / \mathrm{ml}$ at respective $1240 \mathrm{Xg}$ and $2470 \mathrm{Xg}$ centrifugation speeds and the lowest values of $2.125 \mathrm{ml} / \mathrm{ml}$ and $1.750 \mathrm{ml} / \mathrm{ml}$ at respective $1240 \mathrm{Xg}$ and $2470 \mathrm{Xg}$ centrifugation speeds for fibers of green beans compared with lowest values of 2.000 and $1.666 \mathrm{ml} / \mathrm{ml}$ at respective above centrifugation speeds for commercial cellulose. Its look like that extracted fibers from different sources had a significant $(\mathrm{P}<0.05)$ higher ability to absorb or draw from the medium compared with purified commercial cellulose, and this may be due to the composition of these fibers which composited of mixture of soluble and insoluble fibers compared with those described as purified insoluble once such as cellulose. Even though specifically, IDF has higher water binding capacity (Cray, 1995). Esposito et al., (2005) found that water holding capacity of fibers is strictly related to the amount of insoluble fiber and to the granulometry of the by-products. Because of this characteristic, increased dietary fiber in the diet results in an increase in fecal bulk, reduced transit time of fecal material through the large intestine, increased frequency of defecation, improved regularity of defecation, and reduced hardness of stools (Anonymous, 2001). Soft stools reduce the pressure required for elimination of the wastes, thus, less constipation, and resulted in lowering incidence of diseases such as diverticulitis, hemorrhoids, hernias and appendicitis (Meister, 1996 and Anderson, 2009).

Table 4 shows the oil holding capacity of dietary fibers extracted from different vegetables. Results show that the lowest $\mathrm{OHC}$ at $1240 \mathrm{Xg}$ and $2470 \mathrm{Xg}$ centrifugation speeds were 5.910 and $3.809 \mathrm{~g} / \mathrm{g}$, respectively for green peas and the highest values were 6.527 and $5.593 \mathrm{~g} / \mathrm{g}$, respectively for parsley compared with 5.910 and $4.290 \mathrm{~g} / \mathrm{g}$, respectively for commercial cellulose. Generally, all extracted dietary fibers had higher $\mathrm{OHC}$ at $1350 \mathrm{Xg}$ centrifugation speed compared with 
Mesopotamia J. of Agric.

Vol.(41) No.(4 ) 2013
ISSN:2224-9796(Online)

ISSN:1815-316X(Print)

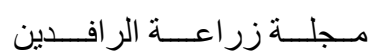

المجلد (41) العدد (4) 2013 الراءين

Table (3): Bulk Density and Water Holding Capacity (WHC) of Dietary fibers Extracted from some Vegetable.

\begin{tabular}{|c|c|c|c|c|c|c|c|c|c|c|c|}
\hline \multirow[t]{2}{*}{ Dietary fibers } & \multirow[t]{2}{*}{$\begin{array}{c}\text { Initial } \\
\text { weight, } \\
\mathrm{g}\end{array}$} & \multirow[t]{2}{*}{$\begin{array}{c}\text { Initial } \\
\text { volume, } \\
\text { ml }\end{array}$} & \multirow[t]{2}{*}{$\begin{array}{c}\text { Bulk } \\
\text { Density, } \\
\text { g/ml }\end{array}$} & \multicolumn{2}{|c|}{$\begin{array}{l}\text { Increasing in weight } \\
\text { after centrifugation at } \\
1240 \mathrm{Xg} \text { for } 10 \mathrm{~min}\end{array}$} & \multicolumn{2}{|c|}{$\begin{array}{l}\text { Increasing in volume } \\
\text { after centrifugation at } \\
1240 \mathrm{Xg} \text { for } 10 \mathrm{~min}\end{array}$} & \multicolumn{2}{|c|}{$\begin{array}{l}\text { Increasing in weight after } \\
\text { centrifugation at } 2470 \mathrm{Xg} \\
\text { for } 20 \mathrm{~min}\end{array}$} & \multicolumn{2}{|c|}{$\begin{array}{l}\text { Increasing in volume after } \\
\text { centrifugation at } 2470 \mathrm{Xg} \\
\text { for } 20 \mathrm{~min}\end{array}$} \\
\hline & & & & Weight, $\mathrm{g}$ & $\mathrm{g} / \mathrm{g}$ & $\begin{array}{c}\text { Volume, } \\
\mathrm{ml}\end{array}$ & $\mathrm{ml} / \mathrm{ml}$ & Weight, $\mathrm{g}$ & $\mathrm{g} / \mathrm{g}$ & $\begin{array}{c}\text { Volume, } \\
\text { ml }\end{array}$ & $\mathrm{ml} / \mathrm{ml}$ \\
\hline Celery & 0.15 & 0.35 & 0.429 & $\begin{array}{c}1.1014 \\
\pm 0.085 \mathrm{C} \\
\end{array}$ & $\begin{array}{c}7.342 \\
\pm 0.003 \mathrm{C} \\
\end{array}$ & $\begin{array}{c}1.0 \\
\pm 0.05 \mathrm{AB} \\
\end{array}$ & $\begin{array}{c}2.857 \\
\pm 0.143 \mathrm{BC} \\
\end{array}$ & $\begin{array}{c}0.8532 \\
\pm 0.0002 \mathrm{AB} \\
\end{array}$ & $\begin{array}{c}5.688 \\
\pm 0.002 \mathrm{C} \\
\end{array}$ & $\begin{array}{c}0.9 \\
\pm 0.05 \mathrm{AB} \\
\end{array}$ & $\begin{array}{c}2.571 \\
\pm 0.143 \mathrm{~B} \\
\end{array}$ \\
\hline Parsley & 0.15 & 0.3 & 0.500 & $\begin{array}{c}1.0847 \\
\pm 0.002 \mathrm{E} \\
\end{array}$ & $\begin{array}{c}7.231 \\
\pm 0.001 \mathrm{E} \\
\end{array}$ & $\begin{array}{c}1.0 \\
\pm 0.05 \mathrm{AB} \\
\end{array}$ & $\begin{array}{c}3.333 \\
\pm 0.167 \mathrm{~B} \\
\end{array}$ & $\begin{array}{c}0.7166 \\
\pm 0.001 \mathrm{AB} \\
\end{array}$ & $\begin{array}{c}4.777 \\
\pm 0.001 \mathrm{~F} \\
\end{array}$ & $\begin{array}{c}0.75 \\
\pm 0.05 \mathrm{BC} \\
\end{array}$ & $\begin{array}{c}2.500 \\
\pm 0.167 \mathrm{BC} \\
\end{array}$ \\
\hline Red Radish & 0.15 & 0.25 & 0.600 & $\begin{array}{c}1.0906 \\
\pm 0.003 \mathrm{D} \\
\end{array}$ & $\begin{array}{c}7.271 \\
\pm 0.002 \mathrm{D} \\
\end{array}$ & $\begin{array}{c}1.0 \\
\pm 0.05 \mathrm{AB}\end{array}$ & $\begin{array}{c}4.000 \\
\pm 0.20 \mathrm{~A} \\
\end{array}$ & $\begin{array}{c}0.8184 \\
\pm 0.369 \mathrm{~B} \\
\end{array}$ & $\begin{array}{c}5.456 \\
\pm 0.003 \mathrm{D} \\
\end{array}$ & $\begin{array}{c}0.65 \\
\pm 0.05 \mathrm{CD} \\
\end{array}$ & $\begin{array}{c}2.600 \\
\pm 0.20 \mathrm{~B}\end{array}$ \\
\hline Dark Radish & 0.15 & 0.225 & 0.667 & $\begin{array}{c}1.1125 \\
\pm 0.005 \mathrm{~B} \\
\end{array}$ & $\begin{array}{c}7.417 \\
\pm 0.003 \mathrm{~B} \\
\end{array}$ & $\begin{array}{c}1.0 \\
\pm 0.05 \mathrm{AB} \\
\end{array}$ & $\begin{array}{c}4.444 \\
\pm 0.222 \mathrm{~A} \\
\end{array}$ & $\begin{array}{c}0.8706 \\
\pm 0.0006 \mathrm{AB} \\
\end{array}$ & $\begin{array}{c}5.804 \\
\pm 0.004 \mathrm{~B} \\
\end{array}$ & $\begin{array}{c}0.8 \\
\pm 0.05 \mathrm{BC} \\
\end{array}$ & $\begin{array}{c}3.555 \\
\pm 0.222 \mathrm{~A} \\
\end{array}$ \\
\hline Green beans & 0.15 & 0.4 & 0.375 & $\begin{array}{c}0.8830 \\
\pm 0.003 \mathrm{~F} \\
\end{array}$ & $\begin{array}{c}5.887 \\
\pm 0.02 \mathrm{~F} \\
\end{array}$ & $\begin{array}{c}0.85 \\
\pm 0.05 \mathrm{AC} \\
\end{array}$ & $\begin{array}{c}2.125 \\
\pm 0.125 \mathrm{CD} \\
\end{array}$ & $\begin{array}{c}0.7672 \\
\pm 0.0004 \mathrm{AB} \\
\end{array}$ & $\begin{array}{c}5.115 \\
\pm 0.003 \mathrm{E} \\
\end{array}$ & $\begin{array}{c}0.7 \\
\pm 0.05 \mathrm{BCD} \\
\end{array}$ & $\begin{array}{c}1.750 \\
\pm 0.125 \mathrm{CD} \\
\end{array}$ \\
\hline Green peas & 0.15 & 0.35 & 0.429 & $\begin{array}{c}0.7810 \\
\pm 0.002 \mathrm{G} \\
\end{array}$ & $\begin{array}{c}5.207 \\
\pm 0.002 \mathrm{G} \\
\end{array}$ & $\begin{array}{c}0.75 \\
\pm 0.05 \mathrm{C} \\
\end{array}$ & $\begin{array}{c}2.143 \\
\pm 0.143 \mathrm{D} \\
\end{array}$ & $\begin{array}{c}0.7157 \\
\pm 0.0001 \mathrm{AB} \\
\end{array}$ & $\begin{array}{c}4.771 \\
\pm 0.001 \mathrm{BF} \\
\end{array}$ & $\begin{array}{c}0.7 \\
\pm 0.05 \mathrm{BCD} \\
\end{array}$ & $\begin{array}{c}2.000 \\
\pm 0.143 \mathrm{BCD} \\
\end{array}$ \\
\hline Tomato peels & 0.15 & 0.5 & 0.300 & $\begin{array}{c}1.3915 \\
\pm 0.005 \mathrm{~A} \\
\end{array}$ & $\begin{array}{c}9.277 \\
\pm 0.003 \mathrm{~A} \\
\end{array}$ & $\begin{array}{c}1.2 \\
\pm 0.05 \mathrm{~A}\end{array}$ & $\begin{array}{c}2.400 \\
\pm 0.02 \mathrm{CD} \\
\end{array}$ & $\begin{array}{c}1.2755 \\
\pm 0.005 \mathrm{~A}\end{array}$ & $\begin{array}{c}8.503 \\
\pm 0.25 \mathrm{~A} \\
\end{array}$ & $\begin{array}{c}1.0 \\
\pm 0.05 \mathrm{~A}\end{array}$ & $\begin{array}{c}2.000 \\
\pm 0.5 \mathrm{BCD}\end{array}$ \\
\hline Cellulose & 0.15 & 0.3 & 0.500 & $\begin{array}{c}0.6161 \\
\pm 0.004 \mathrm{H} \\
\end{array}$ & $\begin{array}{c}4.107 \\
\pm 0.002 \mathrm{H} \\
\end{array}$ & $\begin{array}{c}0.6 \\
\pm 0.05 \mathrm{D}\end{array}$ & $\begin{array}{c}2.000 \\
\pm 0.167 \mathrm{D} \\
\end{array}$ & $\begin{array}{c}0.5053 \\
\pm 0.0003 \mathrm{C} \\
\end{array}$ & $\begin{array}{c}3.367 \\
\pm 0.01 \mathrm{G} \\
\end{array}$ & $\begin{array}{c}0.5 \\
\pm 0.05 \mathrm{D}\end{array}$ & $\begin{array}{c}1.666 \\
\pm 0.002 \mathrm{D} \\
\end{array}$ \\
\hline
\end{tabular}

Values are the mean of three numbers of experiments.

Different letters in the same column means that there are significantly $(\mathrm{P}<0.05)$ differences. 
Mesopotamia J. of Agric.

Vol.(41) No.(4 ) 2013
ISSN:2224-9796(Online)

ISSN:1815-316X(Print)

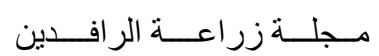

المجلد (41) العدد (4) 2013

Table (4): Oil Holding Capacity (OHC) of Dietary fibers Extracted from some Vegetable.

\begin{tabular}{|c|c|c|c|c|c|c|c|c|c|c|}
\hline \multirow[t]{2}{*}{ Dietary fibers } & \multirow[t]{2}{*}{$\begin{array}{c}\text { Initial } \\
\text { weight, } g\end{array}$} & \multirow[t]{2}{*}{$\begin{array}{l}\text { Initial } \\
\text { volume, } \\
\text { ml }\end{array}$} & \multicolumn{2}{|c|}{$\begin{array}{l}\text { Increasing in weight after } \\
\text { centrifugation at } 1240 \mathrm{Xg} \\
\text { for } 10 \mathrm{~min}\end{array}$} & \multicolumn{2}{|c|}{$\begin{array}{l}\text { Increasing in volume } \\
\text { after centrifugation at } \\
1240 \mathrm{Xg} \text { for } 10 \mathrm{~min}\end{array}$} & \multicolumn{2}{|c|}{$\begin{array}{l}\text { Increasing in weight } \\
\text { after centrifugation at } \\
2470 \mathrm{Xg} \text { for } 20 \mathrm{~min}\end{array}$} & \multicolumn{2}{|c|}{$\begin{array}{l}\text { Increasing in volume } \\
\text { after centrifugation at } \\
2470 \mathrm{Xg} \text { for } 20 \mathrm{~min}\end{array}$} \\
\hline & & & Weight, $\mathrm{g}$ & $\mathrm{g} / \mathrm{g}$ & Volume, ml & $\mathrm{ml} / \mathrm{ml}$ & Weight, $\mathrm{g}$ & $\mathrm{g} / \mathrm{g}$ & Volume, $\mathrm{ml}$ & $\mathrm{ml} / \mathrm{ml}$ \\
\hline Parsley & 0.15 & 0.30 & $\begin{array}{c}0.9791 \\
\pm 0.0001 \mathrm{~A}\end{array}$ & $\begin{array}{c}6.527 \\
\pm 0.001 \mathrm{~A}\end{array}$ & $\begin{array}{c}1.00 \\
\pm 0.05 \mathrm{~A}\end{array}$ & $\begin{array}{c}3.333 \\
\pm 0.167 \mathrm{AB}\end{array}$ & $\begin{array}{c}0.8089 \\
\pm 0.0004 \mathrm{~A}\end{array}$ & $\begin{array}{c}5.393 \\
\pm 0.013 \mathrm{~A}\end{array}$ & $\begin{array}{c}0.85 \\
\pm 0.05 \mathrm{~A}\end{array}$ & $\begin{array}{c}2.833 \\
\pm 0.177 \mathrm{AB} \\
\end{array}$ \\
\hline Red Radish & 0.15 & 0.25 & $\begin{array}{c}0.9135 \\
\pm 0.0004 \mathrm{D}\end{array}$ & $\begin{array}{c}6.090 \\
\pm 0.003 \mathrm{~A} \\
\end{array}$ & $\begin{array}{c}0.95 \\
\pm 0.05 \mathrm{~A}\end{array}$ & $\begin{array}{c}3.800 \\
\pm 0.20 \mathrm{~A}\end{array}$ & $\begin{array}{c}0.6769 \\
\pm 0.0019 \mathrm{C}\end{array}$ & $\begin{array}{c}4.513 \\
\pm 0.013 \mathrm{C} \\
\end{array}$ & $\begin{array}{c}0.7 \\
\pm 0.05 \mathrm{~A}\end{array}$ & $\begin{array}{c}2.800 \\
\pm 0.2 \mathrm{AB} \\
\end{array}$ \\
\hline Dark Radish & 0.15 & 0.225 & $\begin{array}{c}0.8947 \\
\pm 0.0002 \mathrm{E} \\
\end{array}$ & $\begin{array}{c}5.965 \\
\pm 0.002 \mathrm{~A} \\
\end{array}$ & $\begin{array}{c}0.90 \\
\pm 0.05 \mathrm{~A} \\
\end{array}$ & $\begin{array}{c}4.000 \\
\pm 0.223 \mathrm{~A} \\
\end{array}$ & $\begin{array}{c}0.5861 \\
\pm 0.0001 \mathrm{G} \\
\end{array}$ & $\begin{array}{c}3.907 \\
\pm 0.001 \mathrm{G} \\
\end{array}$ & $\begin{array}{c}0.6 \\
\pm 0.05 \mathrm{~A} \\
\end{array}$ & $\begin{array}{c}2.666 \\
\pm 0.223 \mathrm{~B} \\
\end{array}$ \\
\hline Green beans & 0.15 & 0.40 & $\begin{array}{c}0.9558 \\
\pm 0.0006 \mathrm{C} \\
\end{array}$ & $\begin{array}{c}6.372 \\
\pm 0.006 \mathrm{~A} \\
\end{array}$ & $\begin{array}{c}0.95 \\
\pm 0.05 \mathrm{~A} \\
\end{array}$ & $\begin{array}{c}2.375 \\
\pm 0.125 \mathrm{CD} \\
\end{array}$ & $\begin{array}{c}0.5974 \\
\pm 0.0004 \mathrm{~F} \\
\end{array}$ & $\begin{array}{c}3.983 \\
\pm 0.002 \mathrm{~F} \\
\end{array}$ & $\begin{array}{c}0.6 \\
\pm 0.05 \mathrm{~A} \\
\end{array}$ & $\begin{array}{c}1.500 \\
\pm 0.125 \mathrm{CD} \\
\end{array}$ \\
\hline Green peas & 0.15 & 0.35 & $\begin{array}{c}0.8403 \\
\pm 0.0005 \mathrm{G} \\
\end{array}$ & $\begin{array}{c}5.910 \\
\pm 0.003 \mathrm{~A} \\
\end{array}$ & $\begin{array}{c}0.85 \\
\pm 0.05 \mathrm{~A} \\
\end{array}$ & $\begin{array}{c}2.429 \\
\pm 0.143 \mathrm{CD} \\
\end{array}$ & $\begin{array}{c}0.5714 \\
\pm 0.0002 \mathrm{H} \\
\end{array}$ & $\begin{array}{c}3.809 \\
\pm 0.001 \mathrm{H} \\
\end{array}$ & $\begin{array}{c}0.6 \\
\pm 0.05 \mathrm{~A} \\
\end{array}$ & $\begin{array}{c}1.714 \\
\pm 0.143 \mathrm{CD} \\
\end{array}$ \\
\hline Tomato peels & 0.15 & 0.50 & $\begin{array}{c}0.9629 \\
\pm 0.0004 \mathrm{~B}\end{array}$ & $\begin{array}{c}6.419 \\
\pm 0.003 \mathrm{~A}\end{array}$ & $\begin{array}{c}0.95 \\
\pm 0.05 \mathrm{~A}\end{array}$ & $\begin{array}{c}1.900 \\
\pm 0.10 \mathrm{D}\end{array}$ & $\begin{array}{c}0.6485 \\
\pm 0.0004 \mathrm{D}\end{array}$ & $\begin{array}{c}4.323 \\
\pm 0.003 \mathrm{D}\end{array}$ & $\begin{array}{c}0.65 \\
\pm 0.05 \mathrm{~A}\end{array}$ & $\begin{array}{c}1.300 \\
\pm 0.10 \mathrm{D}\end{array}$ \\
\hline
\end{tabular}

Values are the mean of three numbers of experiments.

Different letters in the same column means that there are significantly $(\mathrm{P}<0.05)$ differences. 
cellulose; however, some of the extracted fibers (dark radish, green beans and peas) were relatively significant $(\mathrm{P}<0.05)$ more loss of their oil than other fibers and cellulose. The data in the same Table also show the increasing in dietary fibers volumes after oil adding. The increasing volumes were ranged between 1.900 to $4.000 \mathrm{ml} / \mathrm{ml}$ and 1.300 to $2.833 \mathrm{ml} / \mathrm{ml}$ at $1240 \mathrm{Xg}$ and $2470 \mathrm{Xg}$ centrifugation speeds, respectively compared with respective values of 3.000 and $2.166 \mathrm{ml} / \mathrm{ml}$ for cellulose. Results show that most of the extracted fibers were sustainable to retain oil or have good capacity to hold oil. These results may be suggested that the ability of extracted fibers to affect lipid profile and improve serum lipoprotein values by means of their capacity of holding oil might be predictable from the composition of total dietary fibers which contained both soluble and insoluble fibers in which affect collectively. It was speculated that extracted dietary fibers might help to be useful in preventing heart disease indirectly by effect on serum total lipid,

lipoprotein and cholesterol by binding bile acids and analogous in the digestive tract and increasing their excretion in the feces instead be reabsorbed to the body. Recent study by Khogare (2012) confirmed that there was a decrease in serum cholesterol level after supplementation of high fiber diet. Viscous fibers including soluble fibers appeared to exert primary effects on serum cholesterol and LDL-cholesterol values by binding bile acids in the small intestine and increasing their excretion in the feces in which may reduce coronary heart disease (CHD) (Kirby et al., 1981). Anderson et al. (1984) observed that viscous polysaccharides act in the gastrointestinal tract as reducing agents of blood cholesterol by decreasing absorption of cholesterol or fatty acids and decreasing absorption of biliary cholesterol or bile acids.

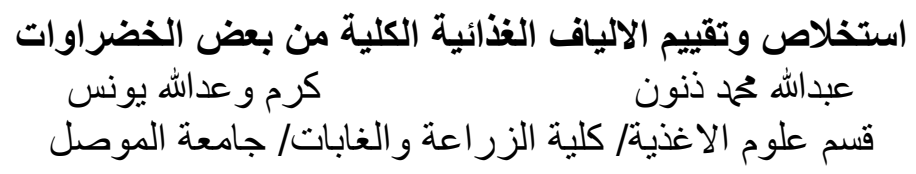

E-mail:dr_thannoun@yahoo.Com

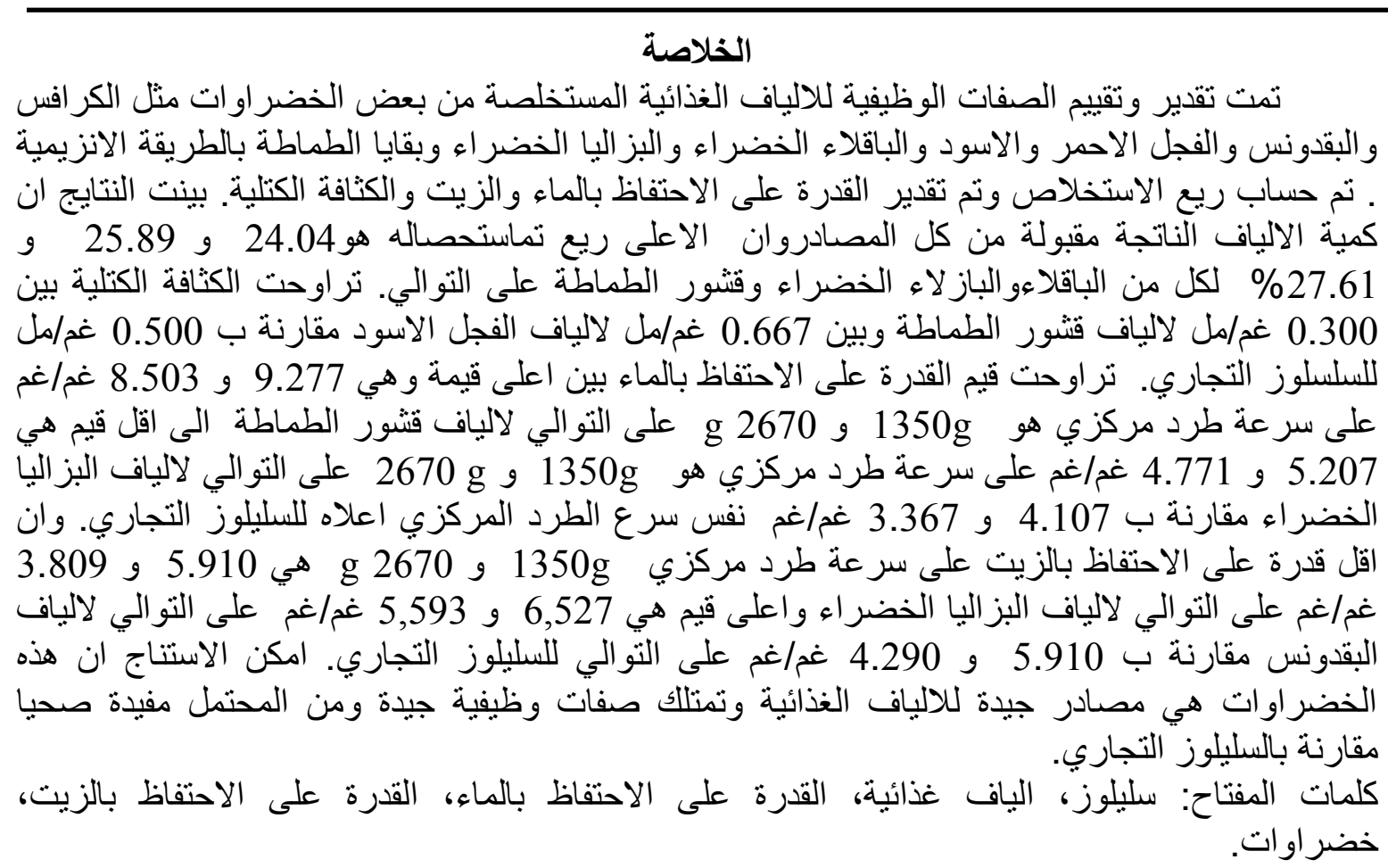




\section{REFERENCES}

Anderson J. W; L. Story; B. Sieling; W. J. Chen; M. S. Petro and J. Story (1984). Hypocholesterolemic effects of oat-bran or bean intake for hypercholesterolemic men. American Journal Clinical Nutrition; 40:11461155.

Anderson, J. W.; B. M. Smith and N. J. Gustafson (1994). Health benefits and practical aspects of high fiber diets. American Journal of Clinical Nutrition 59 suppl, 1242S-7S.

Anderson, J. W.; P. Baird; R. H. Davis Jr; S. Ferreri; M. Knudtson; A. Koraym; V. Waters and C. L. Williams (2009). Health benefits of dietary fiber. Nutrition Reviews ${ }^{\circledR}$ Vol. 67(4):188-205.

Anonymous (1996). American Council on Science and Health (ACSH). Dietary Fiber. A report written for ACSH by Kathleen Meister, December 1996.

Anonymous (2000). Association of Official Analytical Chemists (AOAC). Official Methods of Analysis, $13^{\text {th }}$ Ed., Washington, DC.

Anonymous (2001). American Association of Cereal Chemists (AACC). Dietary Fiber Technical Committee. The definition of dietary fiber. Cereal Foods World 2001;46:112-126.

Anonymous (2011). United State Department of Agriculture (USDA), Agricultural Research Service. 2011. USDA National Nutrient Database for Standard Reference, Release 24.

Brown, L.; B. Rosner; W. W. Willett and F. M Sacks (1999). Cholesterol-lowering effects of dietary fiber: a meta-analysis. American Journal of Clinical Nutrition 69:30-42.

Bunzel, M.; A. Seiler; H. Steinhart (2005). Characterization of dietary fiber lignins from fruits and vegetables using the DFRC method. Journal of Agriculture and Food Chemistry. 53, 9553-9559.

Dalaly, B. K and S. H. Al-Hakim (1987) Food Analysis. Dar Alkutob for printing and publication, University of Mosul.

Esposito F.; G. Arlotti; A. M. Bonifati; A. Napolitano; D. Vitale; V. Fogliano (2005). Antioxidant activity and dietary fiber in durum wheat bran byproducts. Food Research International 38 (10) 1167-1173.

Kirby, R. W; J. W. Anderson; B. Sieling; E. Rees, W. Chen, R. Miller and R. Kay (1981). Oat-bran intake selectively lowers serum low-density lipoprotein cholesterol concentrations of hypercholesterolemic men. American Journal Clinical Nutrition, 34:824-829.

Khogare, D.T. (2012). Effect of dietary fiber on blood lipid profile of selected respondent. International Food Research Journal 19(1): 297-302.

Knoblich, M.; B. Anderson and D. Latshaw (2005). Analyses of tomato peel and seed byproducts and their use as a source of carotenoids. Journal Science of Food Agriculture 85: (7) 1166-1170.

Meister, K. (1996). Dietary Fiber, a report by the American Council on Science and Health. USA. 
Prakongpan, T; A. Nitithamyong and P. Luangpituksa (2002). Extraction and Application of Dietary Fiber and Cellulose from Pineapple Cores. Journal of Food Science Vol 67(4) 1308-1313.

Sreenath, H. K.; K. R. Sudarshanakrishna; N. N. Prasad and K. Santhanam (1996). Characteristics of Some Fiber Incorporated Cake Preparations and their Dietary Fiber Content. Starch/Stärke 48: 72-76.

Steel, R. G. D. andJ. H. Torrei (1980). Analysis of Principales and Pocedures of Statistics. $2^{\text {nd }}$ Ed McGraw Hill, N. Y, USA.

Trowell, H. (1976). Definition of dietary fiber and hypotheses that it is a protective factor in certain diseases. Review articles. American Journal of Clinical Nutrition Vol 29: 417-427.

Weickert, M. O.; M. Mohlig; C. Koebnick; J. J. Holst; P. Namsolleck; M. Ristow; M. Osterhoff; H. Rochlitz; N. Rudovich; J. Spranger and A. F H. Pfeiffer (2005). Impact of cereal fiber on glucose-regulating factors. Diabetologia. 48 (11):2343-53.

Wu, S. C.; P. J. Chien; M. H. Lee and C. F. Chau (2006). Particle Size Reduction Effectively Enhances the Intestinal Health-Promotion Ability of an Orange Insoluble Fiber in Hamsters. Plant Foods Human Nutrition 61 (3):131-7.

Yoshimoto, M.; O. Yamakawa and H. Tanoue (2005). Potential chemopreventive properties and varietal difference of dietary fiber from sweet potato (Ipomoea batatas L.) Root. JARQ: 39 (1), 37 - 43. 